НАУКОВИЙ ВІСНИК

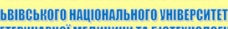

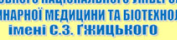
Scientific messenger of Livi National University
Veterinary Medicicine and Biotechnologies

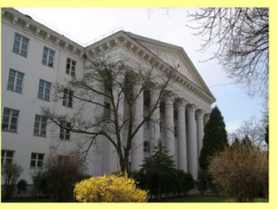

СЕРЯ "ЕКОНОМІчнН НАУКИ"

Том 22 № 94 2020
Науковий вісник Аьвівського національного університету ветеринарної медицини та біотехнологій імені С.3. Гжицького. Серія: Економічні науки

\author{
Scientific Messenger of Lviv National University \\ of Veterinary Medicine and Biotechnologies. \\ Series: Economical Sciences
}

ISSN 2519-2701 print

https://nvlvet.com.ua/index.php/economy

doi: 10.32718/nvlvet-e9406

UDC 546.49.542,1;66

\title{
Influence of mercury on the human and animal organism
}

\author{
I. G. Yaroshovych, B. P. Tchaikovskyj, B. M. Mykychak, T. S. Yaroshovych
}

Stepan Gzhytskyi National University of Veterinary Medicine and Biotechnologies Lviv, Ukraine

Article info

Received 16.01.2020

Received in revised form 19.02.2020

Accepted 20.02.2020

Stepan Gzhytskyi National University of Veterinary Medicine and Biotechnologies Lviv,

Pekarska Str., 50, Lviv, 79010, Ukraine.

Tel.: +38-050-225-08-71

E-mail:kantsvetlv@i.ua
Yaroshovych, I. G., Tchaikovskyj, B. P., Mykychak, B. M., \& Yaroshovych, T. S. (2020). Influence of mercury on the human and animal organism. Scientific Messenger of Lviv National University of Veterinary Medicine and Biotechnologies. Series: Economical Sciences, 21(94), 39-45. doi: $10.32718 /$ nvlvet-e9406

In the list of environmental pollutants, mercury is one of the first places. It is mercury, its inorganic and especially organic compounds belong to extremely toxic substances of the first class of danger.Mercury has been known since ancient times, it is mentioned in the writings of Aristotle. Theophrastus, Pliny the Elder, Vitruvius and other ancient scholars. The Latin name for this metal is "Hydrargium", given to mercury by Greek physician Dioscorides (1st century B.C.), means in translation "silver water". The most important and ancient in Ukraine is the Mykytiv mercury deposit, which was opened in 1879. and operated since 1885. Production of mercury until 1914 was 300-400 t/year (most of it was exported). After the revolution and the war it was slowly recovered (127 tons in 1926), in 1935-1940 it is annually brought to about 300 tons. After the Second World War, the Mykytiv deposit was built. Discovered in it reserves (up to a depth of $300 \mathrm{~m}$ ) were evaluated in 6.000 tons in 1927, after deep drilling was introduced in the 1960s. they have increased slightly. In the world economy, mercury is widely used in the electrical engineering and instrument industry, laboratory and medical practice, in the production of chlorine/alkali, in agriculture (included in fertilizers), in small-scale mining of gold and silver and other fields. No other chemical element belonging to the first class of danger has such wide use in production processes, products, substances and such multivariate penetration into the organism (with air, food, water, through the skin) as mercury and its compounds. The main source of mercury poisoning is mercury vapor and dust of mercury compounds. The toxicity of metallic mercury is due to the fact that while inhaling its vapors more than $80 \%$ of the mercury is absorbed by the brain, kidneys and other internal organs, leading to he devastating consequences primarily on the central nervous system and kidneys. Mercury semi withdrawal period from humans is from 35 to 96 days. The average semi withdrawal period from the blood is 65 days, from hair 72 days, in total from the organism 76 days. A longer semi withdrawal period of mercury from the brain than from other organs has been recorded in experimental animal searches. In humans, high levels of mercury in brain tissue were detected 10 years after it ceased contact with a toxic substance. Mercury poisoning can be acute or chronic. In everyday life, most often find the second option.

Key words: mercury, temperature, semi withdrawal period, acute vapor poisoning, toxic action of mercury and its compounds. thermometer, micromercurialism.

\section{Вплив ртуті на організм людини і тварин}

\author{
І. Г. Ярошович, Б. П. Чайковський, Б. М. Микичак, Т. С. Ярошович
}

Львівський національний університет ветеринарної медицини та біотехнологій імені С. 3. Гжицького, м. Львів, Україна

У списку забруднювачів навколишнього середовища одне із периих місиь посідає ртуть. Саме вона та ї̈ неорганічні і особливо органічні сполуки належать до високо токсичних речовин першого класу небезпек. Ртуть ще відома з прадавніх часів та згадується у працях відомих вчених Аристотеля, Теофраста, Плінія Старшого, Вітрувія та інших давніх учених. Латинська назва цьього металу “гідраргірум”, яку дав ртуті грецький лікар Діоскорид (I ст. до Р.Х.) ие в перекладі означає “срібна вода”. Украйна володіє найважливішим і найдавнішим Микитівським родовищем ртуті, ш⿻ відкрите у 1879 р. і експлуатується із 1885 року. До 
1914 року виробництво ртуті становило 300-400 тонн в рік (велику частину добутої ртуті було експортовано). Після революиії $і$ війни видобування ртуті повільно відновлюється (приблизно 127 тон у 1926 році), у 1935-1940 роках їі видобування доведено щзорічно приблизно до 300 тонн. Після другої світової війни Микитівське родовище розбудовується. В ньому виявлено запаси (до глибини приблизно 300 метрів) оцінювалися у 1927 рочі у 6000 тонн, у 1960-тих роках після введення глибокого буріння вони дещо збільшилися. Світова економіка широко використовує ртуть в електротехнічній промисловості, приладобудуванні, лабораторній та медичній практиці, у виробництві хлору (лугів), у сільському господарстві, яка входить до складу добрив, у дрібномаситабному видобутку золота і срібла та ін. Ні один інший хімічний елемент, шьо належить до першого класу небезпеки, не має такого застосування у виробничих процесах, виробах, речовинах і такої можливості багатоваріантного проникнення в організм (через икіру із водою, повітрям, продуктами харчування), як ртуть та ї̈ сполуки. Основне джерело отруєнь ртуттю - ие пари ртуті та пил ртутних сполук. Токсичність металевої ртуті зумовлена тим, щзо під час вдихання ї̈ парів понад 80\% ртуті поглинається головним мозком, нирками та іншими внутрішніми органами, щуо призводить до руйнівних наслідків у першу чергу для нирок та центральної нервової системи. Період напіввиведення ртуті з організму людини становить від 35 до 96 діб. Середній період напіввиведення з крові - 65 діб, із волосся 72 доби, у иілому з організму - 76 діб. Більш тривалий період напіввиведення ртуті з мозку, ніж з іниих органів, зафіксовано в ході експереминтальних досліджень на тваринах. У людини в мозковій тканині було виявлено високий вміст ртуті через 10 років після того, як вона припинила контакт з токсичною речовиною. Отруєння ртуттю можуть бути гострі або хронічні. У побуті найчастіше зустрічають саме другий варіант.

Ключові слова: ртуть, температура, період напіввиведення, гостре отруєння парами ртуті, токсична дія ртуті і ї̈ сполук. термометр, мікромеркуріалізм.

Описуючи властивості та застосування ртуті, шкідливість та токсичну дію ртуті та ії сполук на організм людини. Представлені приклади гострого отруєння ртуттю та дії хронічного отруєння парами ртуті на клінічному та клітинному рівні, на організм людини.

Напевно все таки, ртуть є одним 3 небагатьох металів, який володіє багатьма цікавими властивостями та великою сферою застосування. Ось для відома лише деякі цікаві факти про цей хімічний елемент.

По-перше, ртуть - це єдиний метал і друга речовина (разом з бромом), що перебуває в рідкому стані при кімнатній температурі. Температура плавлення ртуті $-38,83^{\circ} \mathrm{C}$, а ось підвищення іiі до $+356,7^{\circ} \mathrm{C}$ змушує закипати ртуть та перетворюватися в отруйну пару. Наш організм також містить ртуть, але їі кількість мізерна - 13 міліграмів. Ртуть - речовина, що володіє великою щільністю і питомою вагою. Якщо ви спробуєте підняти заповнене ртуттю, хоча б 10-літрове відро, то у вас нічого не вийде. Вагу ртуті вперше виміряв у 1627 році Роберт Бойль: 1 літр ртуті важить приблизно 13,6 кг, на це ж число щільність ртуті більша за густину води. Якщо вкинути залізне ядро у наповнену ванну ртуттю - воно не потоне, а буде плавати наче гумовий м'ячик (Opeida \& Shvaika, 2008; Biletskyi, 2013).

Ртуть є унікальною речовиною: це рідкий метал за звичайної температури, сріблястого кольору із своєрідними фізичними властивостями. У давнину іiі називали “срібною водою” або “живим сріблом”. Цей метал легко утворює сполуки з органічними та неорганічними речовинами. Сплави металів ртуті з - золотом, сріблом, міддю, цинком, свинцем - називаються амальгами.

Ртуті характерна висока летючість, тобто вона може випаровуватися навіть при мінусовій температурі, іiі пари не мають ані кольору, ані запаху, ані смаку, має здатність до утворення джерел вторинного забруднення (так зване депо сорбованої ртуті) (Rice et al., 2014).

Найвідоміші з історії випадки масового отруєння людей ртуттю наведені в табл. 1.

\section{Таблиця 1}

Випадки масового отруєння ртуттю

\begin{tabular}{lcc}
\hline \multicolumn{1}{c}{ Місце } & Рік & Кількість потерпілих \\
\hline Мінамата & $1953-1983$ & Понад 30 тис. осіб \\
(Японія) & (728 загиблих) \\
Ніїга́та (Японія) & $1964-1965$ & 646 осіб \\
Гватемала & $1963-1965$ & 45 осіб \\
Китай & 1967 & 144 осіб \\
Пакистан & 1969 & 100 осіб \\
Ірак & 1956 & 100 осіб \\
Ірак & 1960 & 1002 осіб \\
Ірак & 1971 & 40 тис. осіб (650 загиблих) \\
\hline
\end{tabular}

Світова економіка широко використовує ртуть в приладобудуванні і електротехнічній промисловості, медичній і лабораторній практиці, у виробництві хлору (лугів), у сільському господарстві (входить до складу добрив), у дрібномасштабному видобутку золота і срібла та інших сферах (Biletskyi, 2013).

Забруднювачами навколишнього середовища, $\epsilon$ :

1. Виробництво хлору та каустику ртутним методом;

2. Виробництво віскозного волокна;

3. Виробництво і застосування:

- електротехнічних приладів, що містять ртуть (випрямлячів змінного струму, ртутних контактів, ртутно-толуолових терморегуляторів тощо);

- електричних ламп розжарювання, кварцових, люмінесцентних і енергоощадних ламп, рентгенівських трубок;

- вибухових речовин на основі гримучої ртуті;

- медичних препаратів, засобів для дезінфекції, антисептиків, косметичних мазей, пестицидів у сільському господарстві тощо;

- процесів хімічного синтезу із застосуванням ртуті як каталізатора;

- у стоматології з використанням амальгамних зубних пломб.

Будь який інший хімічний елемент, який належить до першого класу небезпеки, не має такого масштабного застосування у виробничих процесах, виробах, речовинах ще й такої багатоваріантної можливості 
проникнення в організм (із повітрям, водою, продуктами харчування, через шкіру), як ртуть та їі сполуки.

Вже відомо, що ртуть міститься в морській воді. На даний час встановлено, що дрібні риби мають здатність накопичувати цю речовину. Хижаки риб і птахів, які полюють на дрібну рибу, можуть зберігати ртуть в організмі в ще більш високих концентраціях. Оселедець містить приблизно 0,01 проміле ртуті, в акули показник перевищує 1 проміле (Opeida \& Shvaika, 2008).

Американські вчені, що проводили дослідження риб на вміст ртуті, виявили цю речовину в кожній рибі. При цьому у 25 \% риб ртуть вище допустимого рівня вмісту. В групу ризику потрапили тунець і лобстер. Екологи б'ють на сполох, попереджаючи про небезпеку вживання риби та інших морепродуктів, втім, компанії із вилову риб зі зрозумілих причин називають це “страшилками".

Знадобилося вісім років ретельних досліджень, щоб з'ясувати, що вживання в їжу риби та морепродуктів, забруднених органічними сполуками ртуті із відходів, що скидало у воду хімічне підприємство Chisso Corporation i $є$ причиною захворювання. Із за тривалого вживання в їжу забруднених морепродуктів постраждало, за офіційними даними, понад 30 тисяч мешканців міста, третина з них не за довго померла. У Мінаматі до тепер про страшну трагедію нагадують обличчя потерпілих спотворені хворобою та розумово відсталі діти (Pirrone et al., 2001; Moeseenko et al., 2005).

Тільки через більш як 50 років Програма ООН із навколишнього середовища (ЮНЕП) опублікувала “Глобальний звіт з оцінки ртуті", що стосується забруднення навколишнього середовища ртуттю в глобальному масштабі та шкоди, що завдається здоров ю людини у зв'язку із забрудненням. Вже у 2009 році було прийнято рішення про розроблення конвенції (юридично зобов'язуючого документа) щодо зниження ризиків, пов'язаних із використанням ртуті. У 2013 році членами ООН було погоджено новий міжнародний документ з проблеми ртутного забруднення навколишнього середовища, що отримав назву "Конвенція Мінамата про ртуть”.

Мінаматська конвенція про ртуть (англ. Minamata Convention on Mercury) - міждержавний договір, спрямований на захист здоров'я людей і довкілля від антропогенних викидів і вивільнені ртуті і їі сполук, які можуть призводити до отруєння ртуттю.

Конвенція Мінамата передбачає, що із 2020 року має скоротитися виробництво цілої низки продуктів, вводить обмеження щодо деяких процесів і галузей промисловості, де використовується, вивільняється або випаровується ртуть (Rice et al., 2014).

Також ідеться, серед іншого, про виготовлення медичного обладнання (наприклад термометрів), енергоощадних електроламп, виробництво цементу, гірничодобувну галузь та про роботу вугільних електростанцій.

Отруєння ртуттю можуть бути гострі або хронічні. У побуті найчастіше зустрічають саме другий варіант. Наприклад, дрібні краплі ртуті від розбитого градусника можуть потрапити в щілини підлоги або стіни і бути причиною такого отруєння. При цьому симптоми можуть не проявлятися протягом довгих місяців або виникати повільно і поступово, коли вже ніхто й не пам'ятає про проблему з градусником (Chaikovskyi et al., 2014).

Ртуть $є$ речовиною 1-го класу небезпеки, особливо шкідливі ії пари. У стандартному термометрі міститься до 5 грамів ртуті. Якщо термометр (градусник) розбився в житловій кімнаті об'ємом приміщення 50 куб. метрів, то при випаровуванні всієї ртуті (випаровуватися вона починає при будь-якій плюсовій температурі, причому чим вища температура, тим швидше відбувається випаровування) концентрація парів ртуті в кімнаті досягне 100 мг. на куб. метр, що в 30 тисяч разів більше гранично допустимої концентрації в житловому приміщенні.

\section{Основні симптоми отруєння ртуттю:}

- Слабкість;

- Загальне нездужання;

-Сильні головні болі;

- Втрата апетиту;

- Болі в горлі в процесі ковтання;

- Присмак металу у роті;

- Посилене слиновиділення;

- Набряк і кровоточивість ясен;

- Нудота і блювання.

Насамперед небезпечне отруєння парами ртуті тим, що симптоми не будуть виникати в перебігу тривалого періоду після безпосереднього контакту 3 ртуттю. Так що, якщо ви розбили термометр місяцьдва тому і належним чином не прибрали ртуть що розсипалась, а тепер у вас виникли такі симптоми швиденько до лікаря! (Moeseenko et al., 2005; Opeida \& Shvaika, 2008).

\section{Що робити, аби не отруїтися парами ртуті?}

1. Відкрийте кватирки - забезпечте приплив свіжого повітря і кращу вентиляцію приміщення.

2. Виведіть з приміщення людей, в першу чергу дітей.

3. Обмежте доступ людей в приміщення (закрийте двері) з метою:

- зменшення розносу парів ртуті в суміжні кімнати;

- виключити рознос ртуті по суміжних кімнатах на взутті (постелити килимок або ганчірку, змочену розчином марганцівки, на вході).

Після цього приступаємо до самого процесу демеркуризації (знешкодження ртуті):

- $\quad$ надіньте гумові рукавички, обережно зберіть в будь яку герметичну тару з кришкою, що щільно прилягає (наприклад, в скляну банку) всі осколки термометра, та й звичайно, в першу чергу, кульки ртуті.

Майте на увазі! Питома вага ртуті дуже висока (вона більш ніж в 13 разів важче води). При падінні вона може розсипатися на дрібні кульки i, зазвичай, закотитися в будь яку щілинку. Щоб зібрати всі кульки ртуті без залишку скористайтеся підручними засобами (медичною грушею $з$ тонким наконечником, емальованим совоком, лейкопластирем, скотчем). 
УВАГА! Пам'ятайте, що збір кульок ртуті і скалок термометра потрібно здійснювати від периферії до центру приміщення.

Розсипану по килиму ртуть чи покриттю з дрібними ворсинками або шпаринами, можна після ручного прибирання кульок пропилесосити звичайним побутовим пилососом. Звичайно, пилосос сприятиме роздування парів від зібраної ртуті, але він дозволить бути впевненим у відсутності непомічених вами кульок ртуті, які спокійно продовжують завдавати вам шкоду надалі. Пилесосити потрібно швидко (1-3 хвилини), щоб не надихуватися парами ртуті. Зрозуміло, мішок для збору пилу після цього прибирання потрібно утилізувати, помістивши попередньо в герметичну ємність. Якщо в пилососі система типу “циклон”, весь пил потрібно зсипати в банку з зібраною ртуттю і утилізувати.

Після цього необхідно провести хімічну демеркуризацію. У домашніх умовах можна приготувати розчини 3 підручних засобів. Перманганат калію (марганцівка) із водою або мильно-содовий розчин.

Необхідно почергове застосування обох методів: готується 0,2 \% водний розчин марганцівки (20 г на відро води). Коли є вдома соляна кислота, то в цей розчин додається соляна кислота (за вагою раз на 510 більше ніж суха марганцівка) і цим розчином за допомогою кісточки, щітки, пульверизатора (фарбопульта) обробляється забруднена поверхня. Через 1 годину необхідно змити продукти реакції мильносодовим розчином $-4 \%$ мила в $5 \%$ водному розчині соди. Ці операції необхідно повторювати кілька днів по 2-3 рази на день.

При проведенні цих робіт потрібно думати і про власне здоров'я:

- промити марганцівкою і мильно-содовим розчином рукавички, взуття;

- прополоскати рот і горло слабо-рожевим розчином марганцівки;

- ретельно почистити зуби;

- прийняти 2-3 таблетки активованого вугілля.

На завершення: всі відходи від термометра (градусника), що вам вдалося зібрати в герметичну тару для унеможливлення подальшого забруднення території і приміщення, потрібно здати на підприємство у вашому районі, яке має право на утилізацію ртуті та іiі відходів. Дізнатися про це можна телефоном в довідковій службі, i, можливо, зателефонувавши до надзвичайних служб свого району.

Викидати, як звичайне сміття, ні в якому випадку не можна!

Клінічна картина інтоксикації залежить від форми сполуки ртуті, шляхів надходження до організму та концентрації металу в організмі. Розрізняємо інтоксикацію парами металевої ртуті і іiі неорганічними та органічними сполуками.

Гострі отруєння парами металевої ртуті спостерігаються при аваріях, нещасних випадках за умови порушення заходів безпеки, наприклад, при руйнуванні ртутних термометрів від перегрівання, нагріванні ртуті без дотримання запобіжних заходів та при пожежах. Клінічна картина інгаляційного отруєння розвивається через 8-24 год. і характеризується загальною кволістю, головним болем, болем під час ковтання, підвищеною температурою, катаральними явищами з боку дихальних шляхів (риніт, фарингіт, бронхіт). Пізніше розвивається геморагічний синдром (кровоточивість), починається хворобливість ясен, різко виражені запальні зміни в порожнині рота (ртутний стоматит 3 виразковим процесом на слизовій оболонці ясен), болі в животі, шлункові розлади, ознаки ураження нирок (Nelson \& Bauman, 2003).

Гострі пероральні отрусння неорганічними сполуками ртуті (дихлорид, нітрат, ціанід ртуті) настають при прийманні їх у середину або використанні при способі суїциду. Найбільш токсичним при прийманні у середину $є$ дихлорид ртуті (сулема). Смертельною вважається коливання дози в межах від 0,1 до 0,4 г. Солі ртуті, що потрапляють у шлунковокишковий тракт, всмоктуються дуже швидко через слизову оболонку і викликають глибокі зміни в тканинах організму (Nelson \& Bauman, 2003; Moeseenko et al., 2005; Rice et al., 2014).

При гострих отруєннях ртутними солями набухають ясна, спостерігається їх почервоніння, кровоточивість. 3'являється темна облямівка сульфіду ртуті, розвивається стоматит, розхитуються зуби. Слинні і лімфатичні залози теж набухають це супроводжується рясним виділенням слини. У роті відчувається металевий присмак. У животі спостерігаються різкі болі, з'являється слизовий пронос, зазвичай із кров'ю, блювота, подекуди 3 кров'ю і жовчю, яка в багатьох випадках є для потерпілого рятівною, оскільки тоді виводиться основна маса отруйної солі. Слизова оболонка шлунку і дванадцятипалої кишки покривається масою виразок.

При гострих отруєннях солями ртуті помітних змін з боку легень не відбувається. Серцева діяльність при цьому довгий час залишається нормальною (Joshi et al., 2012).

При гострих отруєннях сулемою спостерігається тотальний некроз епітелію звивистих канальців нирок, що супроводжується його розпадом і злущуванням. Зовнішній вигляд сечі змінюється. Вона, як правило, забарвлюється кров'ю. Вміст білка в сечі збільшується, що є ознакою отруєння сулемою. Зазвичай, на другий день після отруєння виділення сечі припиняється, але через кілька днів анурія змінюється олігурією. У важких випадках отруєння патологічні зміни в нирках швидко розвиваються і через 5-6 днів у результаті гострої ниркової недостатності настає смерть.

В окремих випадках летальний результат отруєння солями ртуті настає через 10-30 і навіть більше ніж 50 діб. Однак відомі блискавичні форми інтоксикації ртутними солями, коли при порівняно невеликих кількостях солі (1 г сулеми, 0,4 г ціаністої ртуті) хворі гинули в непритомному стані протягом 24-36 год. Найбільш характерним при цьому є зовнішній вигляд крові, яка стає рідкою, як вода і чорною, як дьоготь (Moeseenko et al., 2005).

Набагато частіше спостерігаються хронічні отрусння, що виникають при порівняно тривалій роботі (іноді протягом декількох років) у приміщеннях, пові- 
тря яких містить невелику кількість парів ртуті. Концентрація парів ртуті, що викликає хронічні інтоксикації при щоденному впливі на організм, точно не визначена. Однак багато дослідників вказують, що це настає протягом шести місяців у приміщенні, що містить пари ртуті в кількості 0,0001-0,00003 мг/л.

При хронічних отруєннях парами ртуті в першу чергу спостерігаються зміни у нервовій системі (Moiseienko et al., 2004; Chaikovskyi et al., 2014).

У дослідах над тваринами було показано, що при хронічній інтоксикації парами ртуті помітно порушується здатність до вироблення умовних рефлексів. Це призводить до того, що порушується правильна взаємодія окремих частин організму між собою і всього організму в цілому з навколишнім середовищем. Живий організм втрачає здатність швидко пристосовуватися до постійно мінливих умов зовнішнього середовища, в ньому виникають функціональні розлади, які врешті ведуть до патологічних змін (Moeseenko et al., 2005; Joshi et al., 2012).

На першій стадії хронічної інтоксикації хворий починає швидко втомлюватися. 3'являються головні болі, сонливість, апатія, запаморочення - типові ознаки ртутної неврастенії. Спостерігається тремтіння, що посилюється при хвилюванні; яке починається із пальців рук, переходить на повіки, губи, язик зрештою на все тіло. При важкому отруєнні тремтіння посилюється настільки, що хода, їжа, мовлення стають майже неможливими. Спостерігається ослаблення м'язової сили, насамперед - сили розгиначів кисті. Цей симптом ртутного отруєння може з'явитися в перші ж місяці роботи з ртуттю. Причому ступінь ослаблення сили екстензорів збільшується із зростанням стажу роботи, в окремих випадках проявляється незалежно від інших ознак ртутного отруєння. Також присутній розлад шкірної чутливості, смакових відчуттів, різко знижується гострота нюху (Moiseienko et al., 2004; Moeseenko et al., 2005).

Ранніми ознаками ртутного отруєння є збільшення щитоподібної залози, судоми в кінцівках, посилене потовиділення, часті позиви до сечовипускання, що пов'язано з порушенням іннервації сечового міхура.

Поряд з іншими симптомами хронічного ртутного отруєння виникають моно- і поліневрити, як наслідок невралгічного стану - болі в кінцівках і суглобах, а також в області трійчастого нерва; іноді спостерігається незначна асиметрія обличчя (Moiseienko et al., 2004; Moeseenko et al., 2005).

Наслідком хронічного отруєння може бути органічне ураження підкіркових вузлів; 3 цим пов'язана своєрідна нервово-психічна дратівливість (ртутний еретизм). Часто при цьому настає безсоння або сон стає тривожним, наповненим жахами, з'являється безпричинний страх і депресивний стан, пам'ять у людини слабшає. Більш важкі зміни нервової системи, зумовлені ртутними отруєннями (при ртутній енцефалопатіі) тоді порушується психіка та інтелект, людина впадає в стан марення. Важким випадком хронічного отруєння ртуттю $є$ настання смерті, якій передує різке погіршення здоров'я i малокрів'я (Chaikovskyi et al., 2014).
Окрім нервової системи, вражаються й інші органи людини. Відзначаються характерні зміни в порожнині рота, подекуди хронічне отруєння супроводжується гнійним запаленням слизової оболонки (альвеолярна піоррея), описані зміни дихальних шляхів під впливом парів металевої ртуті. Симптомами захворювання $\epsilon$ кашель, болі в грудях, катаральний стан носоглотки. Як правило, зміни у верхніх дихальних шляхах зворотні, вони не бувають важкими і не призводять до втрати працездатності. Найбільш типовим патологічним процесом в області слизової носа $є$ атрофічний риніт, а для нижчих відділів верхніх дихальних шляхів - катаральне запалення, що супроводжується гіпертрофією слизової оболонки, пари ртуті в деяких випадках є причиною бронхітів, бронхіальної астми та емфіземи легенів (Efimova, 2001).

Як показали досліди над тваринами, якщо вміст парів ртуті в повітрі стає значним, то після достатньої кількості експозицій у собак відбуваються зміни в центральній нервовій системі, порушується нейротрофіка, що супроводжується порушеннями функцій печінки і нирок, запально-дистрофічними змінами в цих органах - виникає токсичний гепатит і нефрозонефрит (Geier et al., 2015).

У результаті хронічного ртутного отруєння також відбуваються порушення серцево-судинної системи, це відображено у функціональних змінах міокарда: розвивається частіше чи уповільнене серцебиття, знижується кров'яний тиск, що, на думку дослідників, пояснює блокаду сульфгідрильних груп хеморецепторів судин і контрактильного (звужуючого) апарату стінок судин, а також тонус блукаючого нерву (Moiseienko et al., 2004; Chaikovskyi et al., 2014).

Встановлено, що при ртутній інтоксикації можуть відбуватися істотні зміни в зоровому рецепторі. Ранніми ознаками інтоксикації, при цьому, є акомодаційна астенопія, капілярна гіперемія зорового нерву, набряк сітківки, нерівномірність калібру, звивистість і дистонія сітківки, патологічна зміна поля зору на колір (Moiseienko et al., 2004; Moeseenko et al., 2005).

Хронічне отруєння можливе також при роботі 3 солями ртуті і при використанні ртутних препаратів 3 лікувальною метою. Інтоксикація в цих випадках відбувається в результаті надходження в організм ртутних з'єднань через дихальні шляхи. Наприклад, при просоченні перев'язувальних матеріалів розчинами сулеми з метою надання їм стерильності або через шкіру. Симптоми отруєнь при цьому майже не відрізняються від симптомів, що виникають в результаті хронічного отруєння парами ртуті, однак картина отруєння має свої особливості. Наприклад, пил гримучої ртуті викликає роздратування очей і кон'юнктиви, призводить до дерматитів, свербежу шкіри, іiі набряклості, гнійникового фолікуліту з наступним утворенням виразок. При хронічному отруєнні сулемою на шкірі з'являється висип, подібний до скарлатинозного, він супроводжується сильним свербінням, а після одужання настає лущення шкіри (Moiseienko et al., 2004; Moeseenko et al., 2005).

У проблемі ртутної інтоксикації особливе місце займає питання про мікромеркуріалізм - загальне отруєння організму за хронічного впливу парів ртуті 
та її сполук, що незначною мірою перевищують допустимі санітарні норми, упродовж кількох місяців чи років. Існує думка, що вміст парів ртуті в повітрі в кількостях, в десятки і навіть в сотні разів менших за допустиму санітарну норму $\left(0,01 \mathrm{~m} / \mathrm{M}^{3}\right)$, призводить до хронічних ртутним отруєнь (Pirrone et al., 2001).

Є випадок ртутного отруєння дівчини, яка сама не працювала зі ртуттю, але перебувала в одній кімнаті $з$ подругою, яка працювала на дзеркальній фабриці. Відомий також випадок, коли навіть короткочасне (15-хвилинне) перебування через кожні 2 год в кімнаті, де знаходився перемикач із відкритою поверхнею ртуті, призвело до отруєння (Davidson et al., 2004).

Розрізняють три ступені інтоксикації за впливу дуже малих кількостей ртуті.

Перший ступінь мікромеркуріалізму характерний зниженням працездатності, швидкою стомлюваністю, підвищеною збудливістю.

Другий ступінь мікромеркуріалізму - ці ж явища стають більш вираженими, з'являються головні болі, безпричинний тривожний стан, людина дуже дратівлива, пам'ять помітно слабшає. Слизова оболонка порожнини рота запалюється, ясна починають кровоточити, можна спостерігати катаральні явища верхніх дихальних шляхів, з'являються позиви частого сечовипускання, стілець іноді супроводжується проносами.

При третьому ступені мікромеркуріалзму симптоми мало чим відрізняються від симптомів, характерних для хронічного отруєння ртуттю.

Нерідко клінічна картина отруєнь дуже малими дозами ртуті недостатньо відображає вплив парів ртуті. Тому лікарі замість мікромеркуаріалізму, помилково діагностують хворому розлад нервової системи, захворювання шлунково-кишкового тракту, дихальних шляхів і т. д., не пов'язані з впливом виробничих умов. Тим часом існують дуже тонкі методи, що дозволяють виявляти зміни в організмі під впливом промислових отрут задовго до того, як з'являються ясно виражені ознаки отруєння.

Деякі дослідники довели, що за збудливістю нюхового аналізатора можна судити про стан центральної нервової системи. Оскільки пари ртуті насамперед діють на ЦНС, то за зміною порогової чутливості до запаху різних речовин можна виявити ртутну інтоксикацію задовго до появи клінічних ознак ртутного отруєння. Цей метод був використаний Е. І. Гольдманом для виявлення явищ найбільш ранніх функціональних порушень центральної нервової системи у працюючих із ртуттю. Виявилося, що у більшості працюючих, які зазнають впливу невеликих кількостей парів ртуті при виробництві люмінесцентних ламп, спостерігаються зміни в центральній нервовій системі при відсутності клінічних ознак ртутного отруєння. Було встановлено, що порогова чутливість до запаху розмарину становила 2-4 мл, а до запаху тимолу - 58 мл, причому різниця між пороговою чутливістю до розмарину i тимолу збільшувалася при збільшенні стажу роботи з ртуттю. За даними Л. Г. Охнянской, ця величина i характеризує ступінь отруєння ртуттю. Подібні ольфактометричні зміни спостерігалися також у осіб з клінічними ознаками слабкого ртутного отруєння, тоді як у контрольній групі досліджених працівників, які не стикалися $з$ ртуттю, таких порушень не виявили. Таким чином, за допомогою ольфактометричних досліджень можна виявляти найбільш ранні ознаки ртутного отруєння при відсутності клінічних симптомів.

Необхідним є дослідження змін біоелектричної активності мозку, яка $\epsilon$ першою ознакою інтоксикації центральної нервової системи.

\section{Висновки}

Набагато більш токсичною від парів металевої ртуті, сулеми та інших неорганічних сполук ртуті $\epsilon$ ртутноорганічні сполуки. Небезпека для здоров'я працюючих з ртутноорганічними сполуками настільки велика, що в зоні дихання неможна допускати навіть їх слідів.

Слід зазначити, що гострі отруєння солями ртуті та ртутноорганічними сполуками, так же, як і парами ртуті, зустрічається досить не часто і в більшості випадків пов'язані з пожежами, аваріями та іншими нещасними випадками.

Експериментальні дані, отримані в дослідах над тваринами, а також спостереження за працюючими із ртуттю вказують на те, що навіть невелика кількість парів ртуті в повітрі, якщо вона перевищує природний вміст в атмосфері, має шкідливий вплив на організм.

\section{References}

Biletskyi, V. S. (2013). Mala hirnycha entsyklopediia: u 3 t. D.: Skhidnyi vydavnychyi dim, 2004-2013 (in Ukrainian).

Chaikovskyi, B. P., Hrymaliuk, B. T., Yaroshovych, I. H., Shalko, A. V., \& Pavlyk, N. I. (2014). Hostri otruiennia rtuttiu. Silskyi hospodar. Lviv, 9-10, 32-33 (in Ukrainian).

Chaikovskyi, B. P., Hrymaliuk, B. T., Yaroshovych, I. H., Shalko, A. V., \& Pavlyk, N. I. (2014). Khronichne otruiennia paramy rtuti. Silskyi hospodar. Lviv, 1112, 28-30 (in Ukrainian).

Davidson, P. W., Myers, G. J., \& Weiss, B. (2004). Mercury exposure and child development outcomes. Pediatrics, 113, 1023-1029. https://www.ncbi.nlm. nih.gov/pubmed/15060195.

DSNiP "Hihiienichna klasyfikatsiia pratsi za pokaznykamy shkidlyvosti i nebezpechnosti faktoriv vyrobnychoho sere-dovyshcha, vazhkosti ta napruzhenosti trudovoho protsesu" zatverdzhenyi Nakazom MOZ Ukrainy vid 08.04.2014r. № 248 (in Ukrainian).

DSPiN 2.1.7.728-99 "Pravyla zboru, zberihannia i vydalennia vidkhodiv likuvalno-profilaktychnykh ustanov" (in Ukrainian).

Efimova, N. V. (2001). Rtut': opasnost' real'naja i mnimaja. Irkuts'k (in Russian).

Geier, D. A., King, P. G., Hooker, B. S. et al. (2015). Thimerosal: clinical, epidemiologic and biochemical studies. Clin. Chim. Acta., 444(15), 212-220. doi: 10.1016/j.cca.2015.02.030. 
Joshi, D., Mittal, D. K., Shukla, S., \& Srivastav, A. K. (2012). Therapeutic potential of N-acetyl cysteine with antioxidants ( $\mathrm{Zn}$ and $\mathrm{Se}$ ) supplementation against dimethylmercury toxicity in male albino rats. Exp. Toxicol. Pathol., 64(1-2), 103-108. doi: 10.1016/j.etp.2010.07.001.

Khabarov, A. A., Bulatnikova, V. A., \& Konchinova, O. F. (1997). Biolohichna rol khimichnykh elementov. KHMU Kursk (in Ukrainian).

Moeseenko, V. G., Radomskaja, V. I., Bejd, S. M., \& Hajli, Je. (2005). Toksichnost' rtuti. Medikalveritas, 535-542 (in Russian).

Moiseienko, V. T., Radomskyi, S. M., \& Radomskaia, V. Y. (2004). Intoksikacija chelovecheskogo organizma metallicheskoj rtut'ju. Vestnik DVORAN, 3, 100-110 (in Russian).

Nelson, K. B., \& Bauman, M. L. (2003). Thimerosal and autism? Pediatrics, 111(3), 674-679. doi: 10.1542/peds.111.3.674.

NPAOP 73.1-1.11-12. Pravyla okhorony pratsi pid chas roboty $\mathrm{v}$ khimichnykh laboratoriiakh (in Ukrainian).

Opeida, Y., \& Shvaika, O. (2008). Hlosarii terminiv z khimii. In-t fizyko-orhanichnoi khimii ta vuhlekhimii im. L. M. Lytvynenka NAN Ukrainy, Donetskyi natsionalnyi universytet. Donetsk: "Veber" (in Ukrainian).

Pirrone, N. Costa, P., Pacyna, J. M., \& Ferrara, R. (2001). Atmospheric Mercury Emissions from Anthropogenic and Natural Sources in the Mediterranean Region. Atmospheric Environment, 35, 2997-3006.

Prymirna instruktsiia $\mathrm{z}$ okhorony pratsi pry robotakh iz pryladamy $\mathrm{z}$ rtutnym napovnenniam, zatverdzhena naka-zom Ministerstva promyslovoi polityky Ukrainy vid 19.08.2005 № 311 (in Ukrainian).

Rice, K. M., Walker, E. M., Wu, M. et al. (2014). Environmental mercury and its toxic effects. J. Prev. Med. Public Health., 47(2), 74-83. doi: 10.3961/jpmph.2014.47.2.74

Tan, M., \& Parian, J. E. (2000). Route of decomposition of thiomersal (thimerosal). lnt. J. Pharm., 208(1-2), 23-34. doi: 10.1016/S0378-5173(00)00514-7.

Trakhtenberh, I. M., Krasnokutska, L. M., \& Lubianova, I. P. (2016). Rtut ta yii nebezpeka - problema davnia i nova. Ukrayinskyi zhurnal suchasnykh problem toksykolohii, 1(73) (in Ukrainian).

Zaharov, L. N. (1991). Tehnika bezopasnosti v himicheskih laboratorijah: Himija (in Russian). 